\title{
Discrimination between Low Dietary Zinc and Endotoxin Exposure: A Model Study on Weaning Rats
}

\author{
JACOBUS P. VAN WOUWE, MARCEL VELDHUIZEN, CORNELIS J. A. VAN DEN HAMER, AND \\ JEROEN J. M. DE GOEIJ
}

Department of Radiochemistry, Interfaculty Reactor Institute, Technical University at Delft, Mekelweg 15, 2629 JB Delft [J.P.V.W., M.V., C.J.A.V.D.H., J.J.M.D.G.], and Department of Paediatrics, State University at Leiden, 2300 RC Leiden, the Netherlands [J.P.V.W.]

\begin{abstract}
To establish a parameter for zinc status that is independent of the occurrence of infection, we studied the effects of low dietary zinc and endotoxin in weaning rats $21 \mathrm{~d}$ after ${ }^{65} \mathrm{Zn}$ intubation. We monitored aspects of zinc status (tissue zinc content, ${ }^{65} \mathrm{Zn}$ distribution, and specific ${ }^{65} \mathrm{Zn}$ activity in tissue) and ${ }^{65} \mathrm{Zn}$ metabolism (absorption, excretion, and biologic half-life), as well as weight gain, feed conversion, and dietary zinc use. The low zinc diet induced classical deficiency with losses of bone zinc, resulting in lower content ( 7.4 versus $19.6 \mu \mathrm{mol})$ and higher spec act (17 versus $8 \mathrm{kBq} / \mu \mathrm{mol})$. Other tissue-specific and plasma-specific activities were also higher (overall, 20 versus $8 \mathrm{kBq} / \mu \mathrm{mol}$; plasma, 8 versus $4 \mathrm{kBq} / \mu \mathrm{mol})$. Endotoxin caused lower total-plasma zinc $(0.04$ versus 0.05 $\mu \mathrm{mol})$ but did not affect spec act $(4 \mathrm{kBq} / \mu \mathrm{mol})$; combined endotoxin and low-zinc diet caused low total-plasma zinc $(0.01 \mu \mathrm{mol})$ and high spec act, as did the low-zinc diet alone $(12 \mathrm{kBq} / \mu \mathrm{mol})$. We conclude that plasma-spec act (or stable isotope enrichment) can serve as an index for nutritional zinc status during recurrent infection. (Pediatr Res 28: 332-335, 1990)
\end{abstract}

Groups of children suffering from recurrent upper respiratory tract infection were found to have low hair zinc (1) and high urinary zinc values, as well as lower SD scores of height for age (2). However, these parameters are considered poor indicators of the zinc status of individual patients (3). Moreover, the relationship between zinc status and the health of a child is ambiguous: deficiency either predisposes to recurrent infection (4) or is induced by it (5). In this study involving young male rats, we monitored the zinc status as affected by low dietary zinc and repeated endotoxin exposure. Weight gain, efficiency of feed conversion, and dietary zinc use were measured. Zinc status was characterized by tissue zinc contents, tissue ${ }^{65} \mathrm{Zn}$ distribution, and specific ${ }^{65} \mathrm{Zn}$ activities $\left({ }^{65} \mathrm{Zn}\right.$ activity per mol zinc). Regulation of the zinc status was measured by whole-body ${ }^{65} \mathrm{Zn}$ absorption, excretion, and turnover. On the basis of these results, we evaluated the suitability of the parameters studied to discriminate between low zinc intake, endotoxin exposure, and their combination.

Received November 2, 1989; accepted April 27, 1990.

Correspondence and reprint requests: J. P. Van Wouwe, Department of Radiochemistry, Interfaculty Reactor Institute, Technical University at Delft, Mekelweg 15, 2629 JB Delft, the Netherlands.

Supported by Grant 28-1549 of the Dutch Prevention Fund, The Hague, the Netherlands.

\section{MATERIALS AND METHODS}

Animals and diets. Weaning male Wistar rats weighing $\sim 40 \mathrm{~g}$ (HSD/CPB:WU, Centraal Proefdierenbedrijf TNO-Harlan, Zeist, the Netherlands) were first adapted to diets and environment for $2 \mathrm{wk}$. The animals were housed in Macrolon cages with stainless steel lids within a climate-controlled environment with fixed day-night rhythm. The animals were cared for according to Dutch experimental animal guidelines; the protocols were approved by the University Laboratory Animal Care Committee, in accordance with the Laboratory Animal Resources Guidelines of the U.S. National Research Council. Body weight was measured three times a week and the animals were, from the adaptation period on, pair-fed a low-zinc or zinc-adequate semisynthetic purified diet (Table 1) (IRI-OB Hope Farms, Woerden, the Netherlands). Efficiency of feed conversion was calculated from the ratio of daily food intake $(\mathrm{g} / \mathrm{d})$ and body growth rates $(\mathrm{g} / \mathrm{d})$.

High spec act ${ }^{65} \mathrm{Zn}(50 \mathrm{TBq} / \mathrm{mol})$ was obtained from The Radiochemical Center (Amersham, UK). Whole body counting of animals was performed by placing a container with the animal into a tank filled with a scintillation liquid (pseudocumene) and equipped with a photomultiplier connected to a multichannel analyzer (6). The efficiency of this counter for ${ }^{65} \mathrm{Zn}$ was $31 \%$. The ${ }^{65} \mathrm{Zn}$ activity in individual tissues was measured in a gamma counter. Corrections were made for decay and background. The duration of countings was adjusted to ensure an error of $<0.5 \%$ due to counting statistics. The total zinc in diets and tissues was determined in duplicate after freeze-drying and wet ashing with flame Atomic Absorption Spectrometry (model 2380, PerkinElmer Corp., Norwalk, CT).

The results are given as mean \pm SD. Statistical analysis was performed by analysis of variance and sensitivity and specificity were judged by the overlap index, a rank-order statistic that ranges from 0 for an ideal test with no overlap to 1 if the median test result is the same for two disease states. The index does not depend on defining a normal range or estimating the percentage of observations that lie outside the normal range (7). Significant differences are only discussed if the overlap is also less than $50 \%$.

Experimental design. After the adaptation period, the two groups of animals were split at random into four groups of six animals each. One group (D-E) remained on the low-zinc diet and was exposed to E. coli endotoxin (Lipopolysaccharide B; 055B5; Sigma, St. Louis, MO). Group D-S received the low-zinc diet and was given saline. The two other groups were pair-fed on the control diet and were similarly exposed to endotoxin (group C-E) or saline (group C-S). After an overnight fast, we intubated ${ }^{65} \mathrm{Zn}$ (sterile zinc acetate $\mathrm{pH} 5.5,0.07 \mu \mathrm{mol} / \mathrm{kg}$ body $w \mathrm{t}$ ). The intubated amount of zinc was small compared with dietary zinc intakes maintaining metabolic steady state: $0.2 \mu \mathrm{mol} / \mathrm{d}$ for groups D-E and D-S and $1.0 \mu \mathrm{mol}$ for groups C-E and C-S. On 
Table 1. Composition of IRI-OB Diets

\begin{tabular}{|c|c|}
\hline IRI-OB Diet & $\% W t$ \\
\hline Glucose* & 50 \\
\hline Corn starch $\dagger$ & 15 \\
\hline Ovalbumin $\ddagger$ & 20 \\
\hline Sunflower oil§ & 4 \\
\hline$\alpha$-Cellulose $\|$ & 5 \\
\hline Choline Clף & $<1$ \\
\hline Minerals** & 4 \\
\hline Vitamin mix $+\dagger$ & 1 \\
\hline Trace elements拉 & 0.1 \\
\hline Trace elements & $W t\left(\mu \mathrm{mol} \cdot \mathrm{kg}^{-1}\right)$ \\
\hline As & 1 \\
\hline $\mathrm{B}$ & 10 \\
\hline $\mathrm{Co}$ & 2 \\
\hline $\mathrm{Cr}$ & 40 \\
\hline $\mathrm{Cu}$ & 150 \\
\hline $\mathrm{F}$ & 130 \\
\hline $\mathrm{Fe}$ & 1000 \\
\hline I & 2 \\
\hline $\mathrm{Mn}$ & 900 \\
\hline Mo & 2 \\
\hline $\mathrm{Ni}$ & 40 \\
\hline $\mathrm{Se}$ & 2 \\
\hline $\mathrm{Sn}$ & 20 \\
\hline V & 2 \\
\hline $\mathrm{Zn}$ in deficient diet & $30 \S \S$ \\
\hline $\mathrm{Zn}$ in control diet & 150\|\| \\
\hline
\end{tabular}

* C.P.C. Division Cerestar, France.

$\dagger$ Honig's Artikelen, Koog a/d Zaan, the Netherlands.

$\ddagger$ NIVE, Nunspeet, the Netherlands.

$\S$ Union, Antwerp, Belgium.

\| Macherey-Nagel, FRG.

II $3 \mathrm{~g}$ choline is added separately.

** $\mathrm{Na}$ diphosphate $1.5, \mathrm{KCl} 0.7, \mathrm{CaCO}_{3} 1.0, \mathrm{MgSO}_{4} 0.5, \mathrm{Na}$ metasilicate $0.25 \%$.

†† Per kg: vitamin A acetate 16000 and vitamin D $1400 \mathrm{IU} . \mathrm{In} \mathrm{mg/}$ $\mathrm{kg}$ : vitamin $\mathrm{E} 85$, vitamin $\mathrm{K} 2$, riboflavin 12 , niacin 40 , folate 8 , vitamin B-6 15, vitamin B- 12 0.05, Ca pantothenate 35 , menadione 12 , thiamin $\mathrm{HCl} 20$, biotin $0.4 \mu \mathrm{g}$, and myo-inositol 500 .

拉 Added as: $\mathrm{Na}_{2} \mathrm{HAs}_{3} \mathrm{O}_{4} \cdot 7 \mathrm{H}_{2} \mathrm{O}, \mathrm{Na}_{2} \mathrm{~B}_{4} \mathrm{O}_{7} \cdot 10 \mathrm{H}_{2} \mathrm{O}, \mathrm{CoSO}_{4} \cdot 7 \mathrm{H}_{2} \mathrm{O}$, $\mathrm{CrCl}_{3} .6 \mathrm{H}_{2} \mathrm{O}, \mathrm{CuSO}_{4} .5 \mathrm{H}_{2} \mathrm{O}, \mathrm{NaF}, \mathrm{FeSO}_{4} .7 \mathrm{H}_{2} \mathrm{O}, \mathrm{KIO}_{3}, \mathrm{MnSO}_{4} \cdot \mathrm{H}_{2} \mathrm{O}$,

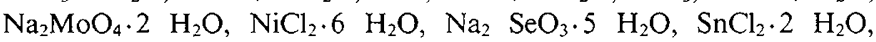
$\mathrm{NH}_{4} \mathrm{VO}_{3}$, and $\mathrm{ZnO}$. All pro analysis quality (E. Merck, Darmstadt, FRG). $\S \S$ By analysis, $30 \pm 2 \mu \mathrm{mol} / \mathrm{kg}$, converted: $2.0 \pm 0.2 \mathrm{ppm}(n=6)$.

\|\| By analysis, $150 \pm 8 \mu \mathrm{mol} / \mathrm{kg}$, converted: $9.8 \pm 0.5 \mathrm{ppm}(n=6)$.

d 1, immediately after the tracer ${ }^{65} \mathrm{Zn}$ intubation, and on $\mathrm{d} 4,7$, 10,13 , and 16 , groups D-E and C-E were injected intraperitoneally with endotoxin $(2 \mathrm{mg} / \mathrm{kg}$ body wt in $0.5 \mathrm{~mL}$ saline), and groups D-S and C-S were injected with an equal volume of sterile saline. Over the first $6 \mathrm{~d}$, feces and urine were collected to monitor ${ }^{65} \mathrm{Zn}$ excretions. Whole-body counting of the animals was performed on $\mathrm{d} 1,2 \mathrm{~h}$ postintubation, and seven times between $\mathrm{d} 7$ and 21 . The whole-body ${ }^{65} \mathrm{Zn}$ activities in the animals at time $t\left(R_{t}\right)$ were related to those measured on $d 1$ $\left(\mathrm{R}_{1}\right)$;

$$
\mathrm{R}=\frac{\mathrm{R}_{\mathrm{t}}}{\mathrm{R}_{\mathrm{I}}}
$$

We plotted in $\mathrm{R}$ versus time, $\mathrm{t}$. A linear relation from $\mathrm{d} 7$ through d 21 was found, which yielded by a least square fit the slope $(\lambda)$ and the intercept, the apparent absorption $\left(A_{a}\right)(8)$. The biologic half-life $\left(T_{b}\right)$ was calculated from:

$$
\mathrm{T}_{\mathrm{b}}=\frac{\ln 2}{\lambda}
$$

inasmuch as these weaning animals grew substantially, the calculated biologic half-life does not reflect purely metabolic turnover.

On d 21, after an overnight fast, all animals were euthanized. After dissection, ${ }^{65} \mathrm{Zn}$ activities and zinc concentrations were measured in plasma, washed erythrocytes, rinsed duodenum, left liver lobe, pancreas, skeletal muscle (flexor digitorum longus), and tibia bone. Values were converted into total tissue activities or contents using, where appropriate, reference values for the tissue masses from their relative weight distribution (9). It is assumed that dietary deficiency does not affect the relative weight distribution (10). The ${ }^{65} \mathrm{Zn}$ activity in tissues not sampled (the carcass) was determined by subtracting the sum of ${ }^{65} \mathrm{Zn}$ activity measured in the sampled tissues from the total activity measured by whole-body counting. The zinc content of the carcass was then calculated by extrapolation from the relationship between total zinc (Table 2 ) and ${ }^{65} \mathrm{Zn}$ activity (Table 3 ) in the soft tissues. The efficiency of feed conversion and dietary zinc use was measured using the quotient of the average amount of zinc $(\mu \mathrm{mol})$ per g body mass on $\mathrm{d} 21$ and of the dietary zinc intake $(\mu \mathrm{mol})$ per $\mathrm{g}$ increase in body weight over the $21-\mathrm{d}$ experimental period.

\section{RESULTS}

Weights and diets. Low zinc intake resulted in growth retardation and anorexia; when this was combined with endotoxin treatment, the anorexia became more severe. Thus, group D-E determined the pair-feeding rate, mean $7 \mathrm{~g} \mathrm{diet} / \mathrm{d}$. For approximately $12 \mathrm{~h}$ after each endotoxin or saline injection, animals exposed to endotoxin were lethargic. The animals fed the lowzinc diet, groups D-S and D-E, were progressively growth retarded from the $1 \mathrm{st} w \mathrm{w}$ on. During the experimental and adaptation period, the average weight increase was $0.3 \pm 0.1 \mathrm{~g} / \mathrm{d}$ in group D-S, versus $0.6 \pm 0.1 \mathrm{~g} / \mathrm{d}$ in group C-S $(p<0.001,4 \%$ overlap). No difference in overall weight gain was observed between groups D-E and D-S. However, weight gain immediately after endotoxin injection was significantly lower $(p<0.005,10 \%$ overlap). This was compensated for in the days that followed. No differences whatsoever in weight gain were seen between groups C-E and C-S. The efficiency of feed conversion was 0.09 $\mathrm{g} / \mathrm{g}$ for the control diet in groups C-S and C-E, versus $0.04 \mathrm{~g} / \mathrm{g}$ in the low-zinc diet groups D-S and D-E.

Zinc status and ${ }^{65} \mathrm{Zn}$ metabolism. The parameters used for the zinc status have been summarized: Table 2 shows the tissue zinc contents, the body weights and the dietary zinc use, Table 3 , the fractional distribution of the intubated ${ }^{65} \mathrm{Zn}$ dose, and Table 4, the specific ${ }^{65} \mathrm{Zn}$ activities in tissues and ${ }^{65} \mathrm{Zn}$ metabolism (apparent absorption, excretion, and biologic half-life). The results in group C-S were used as a reference.

Regarding the zinc status in group D-S, the increase in the whole-body zinc mass lagged behind, resulting in whole-body zinc that was $50 \%$ lower than that in the reference group C-S (Table 2). A different pattern of dose distribution was also shown: lower fractions in bone and higher ones in soft tissues (Table 3). Corresponding higher sp act in tissues were recorded. The ${ }^{65} \mathrm{Zn}$ metabolism in plain deficiency corresponded homeostatically to higher absorption, lower excretion, and slower turnover. The dietary zinc use increased (Table 4).

After endotoxin exposure only, the zinc status in group C-E was marginally different. We found lower plasma zinc content (Table 2) and some modifications of dose distribution: lower bone fractions and, in some cases, higher soft tissue fractions (Table 3). There was little change in sp act. The overall dietary zinc use did not change, nor was there any difference in ${ }^{65} \mathrm{Zn}$ metabolism on the basis of ${ }^{65} \mathrm{Zn}$ absorption, excretion, and biologic half-life (Table 4).

The combined influence of endotoxin and deficiency was evaluated by comparing group D-E with group D-S. In the zinc status, additional endotoxin exposure also resulted in lower zinc 
Table 2. Zinc status measured by tissue content and body wt of rats fed zinc-deficient or control diets*

\begin{tabular}{|c|c|c|c|c|}
\hline & \multicolumn{4}{|c|}{ Group $(n=6$ each $)$} \\
\hline & D-E & $\mathrm{D}-\mathrm{S}$ & C-S & C-E \\
\hline \multicolumn{5}{|l|}{ Tissue } \\
\hline Plasma & $0.01 \pm 0.01^{\mathrm{a}}$ & $0.04 \pm 0.01^{b . c}$ & $0.05 \pm 0.01^{b}$ & $0.04 \pm 0.01^{c}$ \\
\hline Duodenum & $0.07 \pm 0.01^{\mathrm{a}}$ & $0.08 \pm 0.01^{\mathrm{b}}$ & $0.09 \pm 0.01^{b}$ & $0.10 \pm 0.02^{b}$ \\
\hline Liver & $0.68 \pm 0.06^{\mathrm{a}}$ & $0.65 \pm 0.10^{\mathrm{a}}$ & $0.93 \pm 0.29^{b}$ & $1.03 \pm 0.24^{b}$ \\
\hline Pancreas & $0.05 \pm 0.01^{\mathrm{a}}$ & $0.05 \pm 0.01^{\mathrm{a}}$ & $0.07 \pm 0.02^{\mathrm{b}}$ & $0.07 \pm 0.01^{b}$ \\
\hline Heart muscle & $0.05 \pm 0.01^{\mathrm{a}}$ & $0.05 \pm 0.01^{\mathrm{a}}$ & $0.06 \pm 0.01^{a . b}$ & $0.07 \pm 0.01^{\mathrm{b}}$ \\
\hline Muscle & $4.53 \pm 0.87^{a . b}$ & $4.02 \pm 0.39^{\mathrm{a}}$ & $4.46 \pm 0.53^{a, b}$ & $4.80 \pm 1.20^{\mathrm{b}}$ \\
\hline Bone & $6.76 \pm 2.20^{\mathrm{a}}$ & $7.44 \pm 1.44^{\mathrm{a}}$ & $19.60 \pm 1.88^{b}$ & $18.48 \pm 1.56^{\mathrm{b}}$ \\
\hline Carcass & 1.4 & 0.8 & 2.4 & 2.4 \\
\hline Total zinc & 13 & 13 & 27 & 27 \\
\hline \multicolumn{5}{|l|}{ Wt and diet } \\
\hline Initial wt (g) & $41.1 \pm 2.0^{\mathrm{a}}$ & $42.0 \pm 2.1^{\mathrm{a}}$ & $42.3 \pm 2.3^{\mathrm{a}}$ & $41.9 \pm 1.9^{\mathrm{a}}$ \\
\hline Start wt (g) & $45.2 \pm 2.1^{\mathrm{a}}$ & $46.1 \pm 2.3^{\mathrm{a}}$ & $49.4 \pm 2.7^{b}$ & $50.1 \pm 2.1^{\mathrm{b}}$ \\
\hline Final wt $(\mathrm{g})$ & $51.4 \pm 1.9^{a}$ & $51.7 \pm 3.1^{\mathrm{a}}$ & $63.0 \pm 3.6^{\mathrm{b}}$ & $62.9 \pm 4.9^{\mathrm{b}}$ \\
\hline Food consumed $(\mathrm{g})$ & $140 \pm 2^{a}$ & $140 \pm 2^{\mathrm{a}}$ & $140 \pm 2^{\mathrm{a}}$ & $140 \pm 2^{a}$ \\
\hline Food conversion $(\mathrm{g} / \mathrm{g})$ & $0.04 \pm 0.01^{\mathrm{a}}$ & $0.04 \pm 0.01^{\mathrm{a}}$ & $0.10 \pm 0.01^{b}$ & $0.09 \pm 0.01^{b}$ \\
\hline Zinc consumed $(\mu \mathrm{mol})$ & $4.2 \pm 0.3^{\mathrm{a}}$ & $4.2 \pm 0.3^{\mathrm{a}}$ & $21.0 \pm 1.2^{\mathrm{b}}$ & $21.0 \pm 1.2^{\mathrm{b}}$ \\
\hline Zinc used $(\mu \mathrm{mol} / \mu \mathrm{mol})$ & $0.37 \pm 0.03^{\mathrm{a}}$ & $0.37 \pm 0.04^{\mathrm{a}}$ & $0.28 \pm 0.02^{b}$ & $0.28 \pm 0.02^{b}$ \\
\hline
\end{tabular}

* Male weaning rats were pair-fed a zinc-deficient (D) or control (C) diet for $21 \mathrm{~d}$ while repeatedly injected with endotoxin (E) or saline (S). Zinc status was measured by tissue content ( $\mu \mathrm{mol} \mathrm{Zn}$ per entire organ). Initial body wt is when received, start wt is after adaptation period. Zinc use is the ratio of gain in body $\mathrm{Zn}$ to dietary $\mathrm{Zn}$ consumed. Values are mean $\pm \mathrm{SD}$. Common superscripts indicate $p>0.05$ (analysis of variance) and $>50 \%$ overlap.

Table 3. Zinc status of rats as measured by fractional dose distribution*

\begin{tabular}{lcccc}
\hline & \multicolumn{4}{c}{ Group $(n=6$ each $)$} \\
\cline { 2 - 5 } & D-E & D-S & C-S & C-E \\
\hline Tissue & & & & \\
$\quad$ Plasma & $0.2 \pm 0.1^{\mathrm{a}}$ & $0.2 \pm 0.1^{\mathrm{a}}$ & $0.2 \pm 0.1^{\mathrm{a}}$ & $0.2 \pm 0.1^{\mathrm{a}}$ \\
Duodenum & $0.7 \pm 0.1^{\mathrm{a}}$ & $0.9 \pm 0.2^{\mathrm{a}}$ & $0.4 \pm 0.1^{\mathrm{b}}$ & $0.5 \pm 0.1^{\mathrm{c}}$ \\
Erythrocytes & $1.9 \pm 0.5^{\mathrm{a}}$ & $1.8 \pm 0.1^{\mathrm{a} . b}$ & $0.9 \pm 0.2^{\mathrm{c}}$ & $1.1 \pm 0.2^{\mathrm{b}}$ \\
Liver & $10.7 \pm 3.1^{\mathrm{a}}$ & $10.2 \pm 3.0^{\mathrm{a}}$ & $3.6 \pm 0.8^{\mathrm{b}}$ & $5.1 \pm 0.7^{\mathrm{c}}$ \\
Pancreas & $0.6 \pm 0.2^{\mathrm{a}}$ & $0.6 \pm 0.3^{\mathrm{a} . \mathrm{b}}$ & $0.3 \pm 0.1^{\mathrm{b}}$ & $0.4 \pm 0.1^{\mathrm{b}}$ \\
Heart mus- & $0.7 \pm 0.2^{\mathrm{a} . \mathrm{b}}$ & $0.5 \pm 0.1^{\mathrm{a}}$ & $0.3 \pm 0.2^{\mathrm{b} . \mathrm{c}}$ & $0.3 \pm 0.1^{\mathrm{c}}$ \\
$\quad$ cle & & & & \\
$\quad$ Muscle & $41.2 \pm 7.6^{\mathrm{a}}$ & $38.8 \pm 11.5^{\mathrm{a} . \mathrm{b}}$ & $20.7 \pm 0.5^{\mathrm{c}}$ & $25.4 \pm 5.2^{\mathrm{b} . \mathrm{c}}$ \\
$\quad$ Bone & $32.0 \pm 13.5^{\mathrm{a}}$ & $37.6 \pm 9.5^{\mathrm{a} b \mathrm{~b}}$ & $63.1 \pm 0.9^{\mathrm{c}}$ & $50.3 \pm 3.2^{\mathrm{b}}$ \\
$\quad$ Carcass & $12.7 \pm 3.2^{\mathrm{a}}$ & $7.9 \pm 3.1^{\mathrm{a}}$ & $10.9 \pm 0.9^{\mathrm{a}}$ & $12.5 \pm 1.9^{\mathrm{a}}$ \\
\hline $\mathrm{R}_{\mathrm{a}}$ & $49.0 \pm 8.5^{\mathrm{a}}$ & $70.5 \pm 5.5^{\mathrm{b}}$ & $47.7 \pm 5.9^{\mathrm{a}}$ & $42.5 \pm 6.1^{\mathrm{a}}$ \\
\hline
\end{tabular}

$*$ Male weaning rats were pair-fed a zinc-deficient (D) or control (C) diet for $21 \mathrm{~d}$ while repeatedly being injected with endotoxin (E) or saline (S). Their $\mathrm{Zn}$ status was measured by fractional dose distribution on $\mathrm{d}$ $21\left(\%{ }^{65} \mathrm{Zn}\right)$ and $\mathrm{R}_{\mathrm{a}}$, total body activity at $\mathrm{d} 21$. Values are mean $\pm \mathrm{SD}$. Common superscripts indicate $p>0.05$ (analysis of variance) and $>50 \%$ overlap.

contents of plasma and duodenum (Table 2). The ${ }^{65} \mathrm{Zn}$ metabolism showed lower apparent absorption, increased excretion and a shorter biologic half-life (Table 4). On the low-zinc diet, the efficiency of feed conversion and overall dietary zinc use remained constant. The comparison of groups D-E and C-S confirmed the combined effects of deficiency and endotoxin treatment.

\section{DISCUSSION}

In the control animals, growth was retarded. The standard growth chart for this breed, when regular food is fed ad libitum, shows a weight gain from $50 \mathrm{~g}$ to $90-100 \mathrm{~g}$ instead of $63 \mathrm{~g}$. This growth retardation was caused by restricted food intake in pairfeeding. Food intake was limited in the case of animals fed the
Table 4. Zinc status of rats as measured by tissue sp act and ${ }^{65} \mathrm{Zn}$ homeostasis*

\begin{tabular}{lcccc}
\hline & \multicolumn{4}{c}{ Group $(n=6$ each $)$} \\
\cline { 2 - 5 } & D-E & D-S & C-S & C-E \\
\hline Tissue & & & & \\
$\quad$ Plasma & $12 \pm 3^{\mathrm{a}}$ & $8 \pm 1^{\mathrm{a}}$ & $4 \pm 1^{\mathrm{b}}$ & $4 \pm 1^{\mathrm{b}}$ \\
Duodenum & $24 \pm 8^{\mathrm{a}}$ & $31 \pm 9^{\mathrm{a}}$ & $6 \pm 1^{\mathrm{b}}$ & $8 \pm 1^{\mathrm{c}}$ \\
Liver & $24 \pm 9^{\mathrm{a}}$ & $32 \pm 9^{\mathrm{a}}$ & $7 \pm 1^{\mathrm{b}}$ & $8 \pm 1^{\mathrm{b}}$ \\
Pancreas & $25 \pm 9^{\mathrm{a}}$ & $32 \pm 4^{\mathrm{a}}$ & $7 \pm 1^{\mathrm{b}}$ & $9 \pm 1^{\mathrm{b}}$ \\
Heart muscle & $26 \pm 9^{\mathrm{a}}$ & $35 \pm 10^{\mathrm{a}}$ & $8 \pm 1^{\mathrm{b}}$ & $10 \pm 1^{\mathrm{c}}$ \\
Muscle & $19 \pm 5^{\mathrm{a}}$ & $25 \pm 12^{\mathrm{a} . \mathrm{b}}$ & $9 \pm 1^{\mathrm{b}}$ & $10 \pm 1^{\mathrm{b}}$ \\
Bone & $12 \pm 1^{\mathrm{a}}$ & $17 \pm 2^{\mathrm{b}}$ & $8 \pm 1^{\mathrm{c}}$ & $9 \pm 1^{\mathrm{c}}$ \\
Overall & $14 \pm 5^{\mathrm{a}}$ & $20 \pm 5^{\mathrm{a}}$ & $8 \pm 1^{\mathrm{b}}$ & $9 \pm 1^{\mathrm{b}}$ \\
& & & & \\
${ }^{65}$ Zn homeostasis & & & & \\
$\mathrm{A}_{\mathrm{a}}(\%$ dose) & $61 \pm 10^{\mathrm{a}}$ & $80 \pm 15^{\mathrm{b}}$ & $62 \pm 10^{\mathrm{a}}$ & $60 \pm 7^{\mathrm{a}}$ \\
$\mathrm{E}_{\mathrm{f}} \mathrm{d} 1-7(\%$ dose) & $43 \pm 13^{\mathrm{a}}$ & $25 \pm 3^{\mathrm{b}}$ & $57 \pm 13^{\mathrm{a}}$ & $51 \pm 13^{\mathrm{a}}$ \\
$\mathrm{E}_{\mathrm{u}}$ d 1-7 (\% dose) & $0.7 \pm 0.1^{\mathrm{a}}$ & $0.3 \pm 0.1^{\mathrm{b}}$ & $1 \pm 0.2^{\mathrm{a}}$ & $0.7 \pm 0.2^{\mathrm{a}}$ \\
$\mathrm{T}_{\mathrm{b}}$ (d) & $47 \pm 10^{\mathrm{a}}$ & $115 \pm 28^{\mathrm{b}}$ & $54 \pm 6^{\mathrm{a}}$ & $42 \pm 10^{\mathrm{a}}$ \\
\hline
\end{tabular}

* Male weaning rats were pair-fed a zinc-deficient (D) or control (C) diet for $21 \mathrm{~d}$ while repeatedly being injected with endotoxin (E) or saline (S). Their $\mathrm{Zn}$ status was measured by tissue sp act $(\mathrm{kBq} / \mu \mathrm{mol})$ and ${ }^{65} \mathrm{Zn}$ homeostasis. $A_{a}$, absorption; $E_{f}$, excretion in feces; $E_{u}$, excretion in urine; and $T_{b}$, biologic half-life. Values are mean $\pm S D$. Common superscripts indicate $p>0.05$ (analysis of variance) and $>50 \%$ overlap.

low-zinc diet. The animals in group C-S had good appetites and adequate efficiency of feed conversion and zinc use. Despite semistarvation, they displayed a normal zinc status, characterized by proper whole-body zinc mass, balanced ${ }^{65} \mathrm{Zn}$ distribution, and appropriate specific ${ }^{65} \mathrm{Zn}$ activities. On this diet, growth rate was adequate in all tissues, as reflected in uniform $\mathrm{sp}$ act over the various tissues. It would appear that the tissue ${ }^{65} \mathrm{Zn}$ uptakes after intubation were proportional to the amount of zinc already present.

Low zinc intake induced in group D-S the classical features: anorexia, less efficient feed conversion, growth retardation, and changes in zinc status, use, and ${ }^{65} \mathrm{Zn}$ metabolism. Bone was most 
severely affected, containing $7.4 \mu \mathrm{mol}$ compared with $19.6 \mu \mathrm{mol}$ zinc in group C-S. Before adaptation, at $42 \mathrm{~g}$ body weight, the bone zinc content in all groups was equal to a calculated value of $\sim 12.3 \mu \mathrm{mol}$ zinc, which means that loss of zinc from bone must have occurred in group D-S. However, the specific ${ }^{65} \mathrm{Zn}$ activity in bone is $2 / 3$ to $1 / 2$ that in soft tissue. This proves that zinc was also taken up despite the net loss. Thus, the net loss is the result of an uptake of zinc as shown by the ${ }^{65} \mathrm{Zn}$ activity in bone, and even larger losses. The whole-body zinc mass is reduced by $\sim 14 \mu \mathrm{mol}$ zinc, in bone alone, by $\sim 12 \mu \mathrm{mol}$. Bone acts as a zinc store to the soft tissues. This confirms the hypothesis of Berg and Kollmer (11), who postulated that low dietary intake mobilizes zinc from the bone. It also explains the low bone zinc after repletion following low intake (12).

Marginal disturbance of the zinc status was induced by endotoxin alone. Besides lower plasma zinc, no characteristics of zinc deficiency were found. We recorded no changes in ${ }^{65} \mathrm{Zn}$ metabolism, and no anorexia, growth retardation, or lower efficiency of food conversion. A fall in plasma zinc after endotoxin was reported for diets that contained maize oil (where we added sunflower oil in the IRI-OB diet), but not for those containing coconut or fish oil (13). Apparently the low plasma zinc is related to dietary factors other than zinc content. The repeated endotoxin exposures-the last injection was $5 \mathrm{~d}$ before dissectionalso failed to cause any accumulation of zinc, which would reflect induction of metallothionein synthesis in the liver, for example, as has been reported under these conditions $(14,15)$. This may be due to the fact that hunger during pair-feeding also induces metallothionein synthesis, or to the fact that the increase in metallothionein is transient $(16,17)$.

The effects of combined low-zinc diet and endotoxin reflect the separate effects of endotoxin (low plasma zinc) and low-zinc diet (deficiency state). The overall dietary zinc use showed a level similar to that in group D-S. The discrepancy between ${ }^{65} \mathrm{Zn}$ absorption and dietary zinc use may be attributed to the experimental conditions: the ${ }^{65} \mathrm{Zn}$ dose was administered to anorectic animals $30 \mathrm{~min}$ before endotoxin. The fast biologic half-life reflects increased metabolic turnover.

Decreased zinc content in bone and, to a lesser extent, in liver and pancreas indicates the low dietary zinc: the values are not affected by endotoxin exposure (Table 2). The same is true for the fractional ${ }^{65} \mathrm{Zn}$ distribution in the liver and duodenum (Table 3). Increased sp act in plasma and all tissues except muscle are equally suitable indicators of low zinc intake (Table 4). Efficiency of feed conversion and dietary zinc use are also characteristics related only to the dietary zinc. However, it is important to realize that the determination of the ${ }^{65} \mathrm{Zn}$ homeostatic response (Table 4) is not sufficient to diagnose deficiency under other special conditions such as endotoxemia.

In laboratory animals, the determination of zinc levels in bone is a reliable method of assessing nutritional zinc status. In humans, however, the use of bone biopsy is not realistic because the changes in zinc content may not be homogeneous $(12,18)$. Moreover, this invasive technique should not be used to screen suspected deficiency.

Under the extreme conditions in these animal experiments, both dietary deficiency and endotoxemia, the results were clear. The combined determination of plasma total zinc (Table 2) and its ${ }^{65} \mathrm{Zn}$ sp act (Table 4) makes it possible to distinguish between plain deficiency (normal zinc, higher sp act), endotoxemia (lower zinc, normal $\mathrm{sp}$ act), and the combination (lower zinc, higher $\mathrm{sp}$ act). Therefore, the use of the radioactive tracer ${ }^{65} \mathrm{Zn}$ adds to the diagnostic potential, but due to the radiation exposure, this longliving nuclide (physic half-life $=244 \mathrm{~d}$ ) is of limited practical use. One solution would be the use of stable zinc tracers, i.e. zinc enriched in ${ }^{70} \mathrm{Zn}$, analyzed with mass spectrometry. However, the assay procedures are more difficult and more expensive than in the case of ${ }^{65} \mathrm{Zn}$. Twenty-one $\mathrm{d}$ after a single dose of $1 \mu \mathrm{mol}$ ${ }^{70} \mathrm{Zn} / \mathrm{kg}$ body weight is ingested, there is a detectable change in the ratio ${ }^{70} \mathrm{Zn} /{ }^{64} \mathrm{Zn}$ in a sample of $1 \mathrm{~mL}$ plasma, the enrichment for ${ }^{70} \mathrm{Zn}$ having been estimated at $\sim 20 \%$ (19).

We conclude that plasma sp act may be of use in diagnosing zinc deficiency in those physiologic and pathologic conditions in which low plasma zinc is due to factors other than zinc status.

\section{REFERENCES}

1. Lombeck I, Wilhelm M, Hafner D, Roloff K, Ohnesorge FK 1988 Hair zinc of young children from rural and urban areas in North Rhine-Westphalia, Federal Republic of Germany. Eur J Pediatr 147:179-183

2. Van Wouwe JP, Van Gelderen HH, Bos JH 1987 Subacute zinc deficiency in children with recurrent upper respiratory tract infection. Eur J Pediatr 146:293-295

3. Van Wouwe JP, De Wolff FA, Van Gelderen HH 1986 Zinc in hair and urine of paediatric patients. Clin Chim Acta 155:77-82

4. Chandra RK 1983 Nutrition, immunity, and infection: present knowledge and future direction. Lancet 1:688-691

5. Sugarman B 1983 Zinc and infection. Rev Infect Dis 5:137-147

6. Van Barneveld AA, Van den Hamer CJA 1984 Intestinal passage and absorption of simultaneously administered ${ }^{64} \mathrm{Cu}$ and ${ }^{65}$ zinc and the effect of feeding in mouse and rat. Nutr Rep Int 29:173-182

7. Hartz AJ 1984 Overlap index, an alternative to sensitivity and specificity in comparing the utility of a laboratory test. Arch Pathol Lab Med 108:65-67

8. Heth DA, Hoekstra WG 1965 Zinc-65 absorption and turnover in rats I. A procedure to determine zinc- 65 absorption and the antagonistic effect of calcium in a practical diet. J Nutr $85: 367-374$

9. Owen CA 1964 Distribution of copper in the rat. Am J Physiol 207:446-448

10. White CL 1988 The effect of zinc deficiency on the body composition of rats. Biol Trace Elem Res 17:175-187

11. Berg D, Kollmer WE 1987 Mobilization of zinc and strontium from bone in zinc deficient rats. In: Brätter P, Schramel $\mathrm{P}$ (eds) Trace Element Analytic Chemistry in Medicine and Biology, Vol 4. W de Gruyter, Berlin, pp 265273

12. Jackson MJ, Jones DA, Edwards RHT 1982 Tissue zinc levels as an index of body status. Clin Physiol 2:333-343

13. Brown G, Hunt V, Wan J, Grimble RF 1987 The differing response of zinc and protein metabolism to Escherichia coli endotoxin in rats fed on diets containing maize, coconut and fish oils. Proc Nutr Soc 46:36(abstr)

14. Abe S, Matsumi M, Tsukioko M, Mizukawa S, Takahashi T, lijima Y, Itano Y, Kosaka F 1987 Metallothionein and zinc metabolism in endotoxin shock rats. Experientia [Suppl] 52:587-594

15. Fukushima T, Iijima Y, Kosaka F 1988 Endotoxin-induced zinc accumulation by liver cells is mediated by metallothionein synthesis. Biochem Biophys Res Commun 152:874-878

16. DiSilvestro RA, Cousins RJ 1984 Mediation of endotoxin-induced changes in zinc metabolism in rats. Am J Physiol 247:E436-E44 1

17. Bremner I, Morrison JN, Wood AM, Arthur JR 1987 Effects of changes in dietary zinc, copper and selenium supply and of endotoxin administration on metallothionein I concentrations in blood cells and urine in the rat. J Nutr 117:1595-1602

18. Nooijen JL, Van den Hamer CJA, Houtman JPW, Schalm SW 1981 Possible errors in sampling percutaneous liver biopsies for determination of trace element status: application to patients with primary biliary cirrhosis. Clin Chim Acta 113:335-338

19. Janghorbani M, Ting BTG, Istfan NW, Young VR 1981 Measurement of ${ }^{68} \mathrm{Zn}$ and ${ }^{70} \mathrm{Zn}$ in human blood in reference to the study of zinc metabolism. Am J Clin Nutr 34:581-591 